\title{
Methylmercury Poisoning in Canadian Indians - The Elusive Diagnosis
}

\author{
BRIAN WHEATLEY, ANDRÉ BARBEAU. THOMAS W. CLARKSON. and LOWELL W. LAPHAM
}

\begin{abstract}
SUMMARY: $A$ World Health Organization Expert Committee has concluded that symptoms of methylmercury poisoning may appear at blood concentrations of 200-500 $\mathrm{ng} \mathrm{Hg} / \mathrm{ml}$. Blood levels in this range have been found in several Indian and Inuit communities in Canada. The syndrome of severe methylmercury poisoning (Hunter-Russell syndrome) is well described. However. diagnosis of less severe cases is difficult. This paper review's the present situation in Canada. The problems of diagnosis currently being encountered are discussed and are illustrated by
\end{abstract}

RESUME: Selon un Comité de l'Organisation Mondiale de la Santé, les symptômes d'empoisonnement au méthylmercure peuvent apparaitre $\dot{a}$ des concentrations sanguines de 200-500 ng $\mathrm{Hg} / \mathrm{ml}$. De tels niveaux ont été trouvés dans plusieurs communautés amérindiennes au Canada. Le syndrome d'intoxication sévère au méthylmercure (Svindrome de HunterRussell) est bien connu. Cependant le diagnostic de cas moins sévères est difficile. Nous étudions la situation au Canada et discutons des problèmes de diagnostic. Nous décrivons un cas chez un individu ayant été exposé sévèrement au méthyl- the case of an individual who had one of the highest blood concentrations (55I ing $\mathrm{Hg} / \mathrm{ml}$ ) ever described in fish-eating populations outside of the outbreaks in Minamata and Niigata in Japan. Although mercury concentrations in brain were estimated to have been in the "symptomatic" range at least once in the w'o lears prior to his death, neurohistological examination was normal. Detailed examination by two teams of neurologists revealed effects that may be associated with methylmercury poisoning but $a$ definitive diagnosis remained elusive.

mercure provenant de poissons. Ce pátient avait un des taux les plus élevés (55I ng $\mathrm{Hg} / \mathrm{ml}$ ) jamais décrits dans des populations consommatrices de poisson, en dehors des épidémies aiguës de Minamata et Niigata au Japon. Cependant les concentrations cérébrales furent au moins une fois, au cours des deux années précédant le décès, dans la zone dite "sympromatique". L'examen neurologique détaillé par deux équipes de spécialistes démontre des signes qui pourraient être associés à une intoxication au méthylmercure, mais un diagnostic définitif demeure difficile.
From the Medical Services Branch. National Health and Welfare Canada and the Clinical Research Institute of Montreal and the Environmental Health Sciences Center. University of Rochester Medical Center. Rochester, New York.

Reprint requests to: Dr. Brian Wheatley, Medical Services Branch. Health and Welfare Canada, Room 1954, Jeanne Mance Building. Tunney's Pasture, Ottawa, KIA 0L3, Canada.

\section{INTRODUCTION}

The dangers of methylmercury first came to world attention in the 1960's following major epidemics of poisoning in Japan (Tsubaki et al., 1967; Katsuma, 1968). Other outbreaks of poisoning have been reported from many parts of the world due to the accidental consumption of seed grain treated with methyl or ethylmercury containing fungicides (World Health Organization, 1974). The largest and best documented of these took place in 1971-72 in Iraq involving over 6,000 hospital admissions and 450 hospital deaths (Bakir et al., 1973).

A Swedish expert group (1971) reviewing the outbreaks in Japan concluded that the lowest blood concentration associated with adverse health effects was about $200 \mathrm{ng}$ $\mathrm{Hg} / \mathrm{ml}$. This analysis became the basis for World Health Organization Food and Agriculture Organization (WHO-FAO) 1972 guidelines on tolerable weekly intakes of methylmercury and for federal guidelines in Canada (Morrison, 1971) and the USA (Kolbye, 1973). Studies on a variety of fish-eating populations revealed that several individuals having a maximum blood concentration of about $200 \mathrm{ng} \mathrm{Hg} / \mathrm{ml}$ did not have signs and symptoms of methylmercury poisoning. A recent review of all available data on exposed populations by a WHO expert group (1976) concluded that signs and symptoms would appear in the most sensitive individual adults at blood concentrations between 200-500 ng Hg/ml. Prenatal effects may occur at lower levels. A safety factor of 10 has been used to define "safe" levels in man. (Swedish Expert Group, 1971)

At high dosage the clinical effects of 
methylmercury are well documented and recognized as the Hunter-Russell syndrome (Hunter \& Russell, 1954). more recently termed "Minamata Disease". Methylmercury is toxic to the central nervous system. Primary signs and symptoms of toxic effects include ataxia, sensory disturbances, intention tremor, and reduction of visual fields. The latter is regarded by many authorities as being the most pathognomonic finding, providing that retinitis pigmentosa and associated conditions have been ruled out. Other symptoms include deafness and dysarthria (Skerfving \& Vostal, 1972). However, at blood levels in the range 200-500 $\mathrm{ng} \mathrm{Hg} / \mathrm{ml}$ the syndrome is less obvious and diagnosis is more difficult for the following reasons:

(a) Factors such as nutritional state, alcohol intake, medications, and age may produce similar clinical findings or potentiate the effects of methylmercury. Observations on experimental animals have suggested that the presence of selenium in the diet may exert a protective effect against methylmercury poisoning (Ganther et al., 1972). However, proof of this effect in man is still lacking (Skerfving, 1978).

(b) There are no definitive "early warning" clinical signs, i.e. clinical specificity is absent.

(c) There are no "early warning" biochemical methods, comparable to the zinc protoporphyrin test for lead or $\beta_{2}$ microglobulin test for cadmium, applicable to methylmercury.

(d) Brain damage possibly occurs before clinical signs and symptoms appear. Grant (1973) obtained experimental evidence consistent with this concept of "silent damage".

(e) Small increments $(0.1 \%$ per year) in the rate of cerebral cell loss may produce severe effects over a period of years (Weiss \& Simon, 1975). At this slow rate, cell loss would be undetectable by present neurohistological techniques. Such cell damage could be produced by methylmercury.

The difficulties are well illustrated by the present situation in Canada where some Indian people have been exposed to mercury over a period of years on a seasonal basis, and a number have been found to have blood methylmercury levels in the 200$500 \mathrm{ng} \mathrm{Hg} / \mathrm{ml}$ range.

\section{CANADIAN SITUATION}

In Canada between 1961 and 1970 , chlor-alkali plants discharged considerable quantities of inorganic mercury into certain river systems in northwestern Ontario (Armstrong \& Hamilton, 1973) and northwestern Quebec (Berkes et al., 1972). It was believed that, in contrast to methylmercury, inorganic mercury was relatively inert in the environment, but in the late 1960's it was shown that inorganic mercury is methylated by micro-organisms in river and lake sediments (Jensen \& Jernelov, 1969), undergoes bioaccumulation up the food chain, and eventually reaches significant levels in predatory fish (Bishop \& Neary, 1976) which are eaten by man. In 1970, this danger was recognized in Northwestern Quebec. An investigation was initiated and testing of fish and people living in these areas was undertaken (Environment Canada, 1972). The areas are remote and are inhabited mainly by Indian groups who depend on fish as a staple part of their diet.

Over the succeeding years, the Medical Services Branch of the Department of National Health and Welfare has carried out a testing program for mercury levels in Native and Northern people across Canada, based on blood and hair sampling. National totals to December 31, 1978 show 34,810 tests have been performed in 356 communities. Approximately $31 \%(10,822)$ of these tests indicated an elevated mercury concentration (blood levels greater than $20 \mathrm{ng} \mathrm{Hg} / \mathrm{ml}), 2.1 \%$ (740) were greater than $100 \mathrm{ng} \mathrm{Hg} / \mathrm{ml}$, and $0.3 \%$ ( 119 tests on 61 individuals) were greater than $200 \mathrm{ng} \mathrm{Hg} / \mathrm{ml}$. However, in Quebec, of 17, 283 tests in 52 communities, $41.5 \%$ (7172) showed elevated levels, $3.4 \%$ (596) were greater than $100 \mathrm{ng} \mathrm{Hg} / \mathrm{ml}$, and $0.5 \%$ (88 tests on 43 individuals) exceeded $200 \mathrm{ng}$ $\mathrm{Hg} / \mathrm{ml}$ (Wheatley, 1979). Of those individuals in Canada found to have levels over $200 \mathrm{ng} \mathrm{Hg} / \mathrm{ml}, 70 \%$ live in northern Quebec.

Clinical examinations have been carried out on a number of persons with known elevated mercury levels (Barbeau et al., 1976 and Prichard, 1976). The assessment of the effects of these elevated mercury levels has, however, proven difficult and has resulted in considerable divergence of opinion among neurologists (Shepard, 1976). The correlation between known mercury levels, neurological findings, histopathological findings, and diagnosis has also proven difficult, not least because of logistical and other difficulties in obtaining all the relevant data on any one individual.

These uncertainties have led to controversy in the popular and scientific literature as to the hazard from methylmercury in the diet (Kahn, 1971, Harada et al., 1976). It is, therefore, important to give close attention to those Indian people in northwestern Ontario and Quebec who have probably experienced higher blood concentrations of methylmercury, than any other fish-eating population in the world, with the exception of the individuals involved in the two Japanese outbreaks.

It is the purpose of this paper to focus on some of the problems involved in establishing the diagnosis of methylmercury poisoning in Canadian Indians.

In the case discussed here, there are records of mercury levels over a period of almost three years, together with the results of two neurological examinations, and, following death, mercury levels in the brain tissue and related histopathological findings. The individual had one of the highest levels of mercury ever detected in Canada.

\section{Case History}

The patient was a male Cree Indian, aged 79 at the time of his death in 1977. For most of his life he lived in remote northwestern Quebec. Fish was a major component of his diet. He had a long (20 years) history of pulmonary tuberculosis and was tested for mercury levels in blood and hair in 1975.

$\mathrm{His}$ blood level then was $551 \mathrm{ng} \mathrm{Hg} / \mathrm{ml}$. He was advised to stop eating fish and to undergo a complete medical examination, with special emphasis on neurological signs and symptoms. His first clinical 
examination took place in October 1975 and a second one was carried out in November 1975. Follow-up visits were made and hair and blood samples were collected. In January 1977, he was admitted to hospital with a diagnosis of intestinal obstruction and pulmonary tuberculosis, and died five days later.

The results of analyses for total mercury in samples of blood and hair are reported in Figure 1. Five hair samples and nine blood samples were taken during the period July 1975-January 1977 and were analyzed using the method of Magos and Clarkson (1972). Each hair was divided into $1 \mathrm{~cm}$ segments and each segment was tested for total and inorganic mercury. This procedure allows recapitulation of past blood concentrations (GiovanoliJakubczak et al., 1974, Al-Sharista ni et al., 1976).

In plotting the data in Figure 1, it was assumed that the growth rate of hair was 1 $\mathrm{cm} / \mathrm{month}$. It was also assumed that the proximal $1 \mathrm{~cm}$ segment reflected a blood concentration one month prior to the collection of the hair sample. Amin-Zaki et al., (1976) made a similar assumption in the comparison of the hair and blood data in the Iraqi outbreak.

Three hair samples overlap for the period June to October 1975. The data agree well and fall within the range of analytical error. In general, the hair and blood data correspond closely, indicating a hair to blood ratio of about $300: 1$, in agreement with other observations on Canadian Indians consuming methylmercury contaminated fish (Clarkson, 1976; Phelps et al., 1979) and with reports on fish eating populations in other parts of the world (W.H.O., 1972).

The outlying single point in the blood data, $551 \mathrm{ng} \mathrm{Hg} / \mathrm{ml}$ in July 1975, may be explained by unusually heavy consumption of mercury contaminated fish just prior to the collection of the blood sample. There is now evidence that unusually high blood concentrations are obtained within 48 hours of the consumption of a meal of fish containing high concentrations of methylmercury (Kershaw et al., 1979).

The hair and blood data viewed as a whole, indicate that this man experienced high exposure during most of 1974 and until the summer of 1975 . Ignoring the outlying blood concentration discussed above, the data indicate that his blood attained a plateau level of a bout 300 to 350 $\mathrm{ng} \mathrm{Hg} / \mathrm{ml}$ for several months. The result of the advice not to eat fish is dramatically illustrated by the falling blood and hair concentrations after August 1975 (Figure 1). Eventually, a new low steady state level was attained corresponding to a blood concentration between 20 and $40 \mathrm{ng}$ $\mathrm{Hg} / \mathrm{ml}$. The concentration in the postmortem blood sample was $24 \mathrm{ng} \mathrm{Hg} / \mathrm{ml}$.

\section{Clinical Examinations}

The patient, together with other members of his family, was referred to Montreal in October 1975 for clinical and neurological examination. He denied any paraesthesia, irritability, depression, or difficulty in walking. He had, however, noticed tremors in his hands for several years and had diminished hearing for some time. He said he had noted difficulty in seeing at a distance, particularly at night. He had a past history of tuberculosis 22 years prior to admission, with an exacerbation three years prior to admission. He stated that he smoked and drank very little.

Blood pressure, pulse, respiration, and temperature were all normal. He had a brawny induration of both lower limbs with weeping lesions, and poor dental health. A soft systolic murmur was noted together with signs of chronic lung disease. He was alert and despite his hearing loss was able to understand a complex situation. He had senile cataracts, although these were not dense. There was some presbyopia. A white opacification on the anterior surface of both lenses was noted.

Audiogram revealed profound bilateral hearing loss. Other cranial nerves were normal. The motor system was within normal limits and touch, pin prick, vibration, proprioception, two point discrimination, and stereognosis were normal. Reflexes were diminished, abdominal responses absent, and plantars were flexor.
Coordination tests revealed an intention tremor which was worse on the right side. Tandem walking and gait were normal. Rapid alternating movements were slightly' impaired bilaterally.

A number of minor hematological abnormalities were detected. Electrocardiogram was normal as was electroencephalogram. Electromyogram, however, gave evidence of a sensory neuropathy. X-ray showed a normal skull and chest findings consistent with healed tuberculosis. EMI scanning revealed mild diffuse cerebral atrophy. He remained well in hospital and no recommendations were made on discharge. The discharge diagnosis stated that "no specific neurological abnormalities which could be clearly' related to mercury intoxication" had been found.

In November 1975, he was again examined, this time by a different team of neurologists near his home in northern Quebec. The findings at this time indicated severe bilateral hypoacusia and bilateral. moderately severe cataracts which were not thought to be sufficient to explain the severe restriction of visual fields. The sensory examination revealed nild impairment of superficial cutaneous sensation near both ankles (in "stocking" fashion) but a severe reduction in the perception of vibration sense (to 3 and $5 \mathrm{sec} / 11$ normal). There was a moderate intention tremor (812 cycles/sec) in both hands. more marked in the right, accompanied by definite adiadokokinesia. Finger-to-nose coordination was markedly impaired (50\% impairment) on the right, moderately on

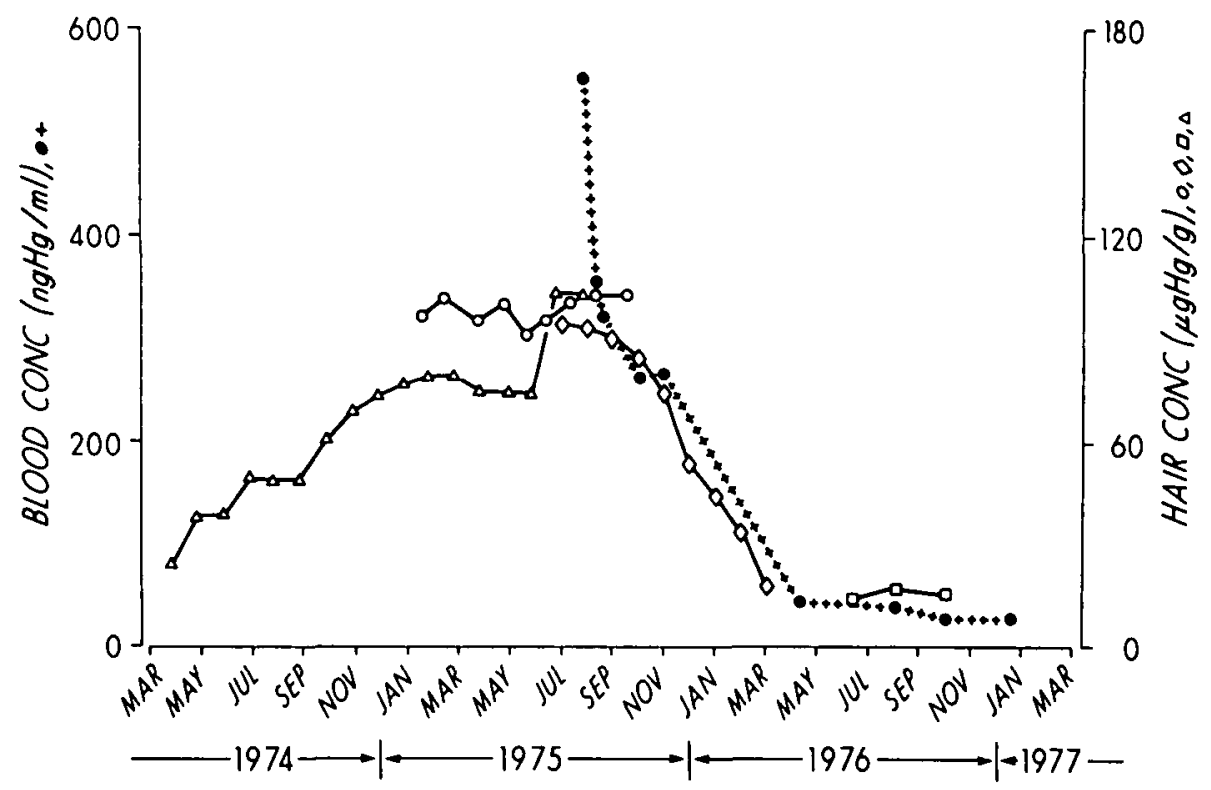

Figure 1 - The concentrations of mercury in blood a nd hair samples collected at different dates. The hair samples were analyzed centimeter by centimeter and a growth rate of $1 \mathrm{~cm}$ /month was assumed (for details, see text). 
the left. Gait ataxia was evident, but there was no Romberg sign. All tendon reflexes were decreased. The mechanical performance tests were impaired bilaterally as compaired to age-matched controls (for example, the patient could correctly place only 7 pegs in $30 \mathrm{sec}$. in the pegboard control normals: more than 10; total motor performance score $30 \mathrm{I}$ as compared to over 500 in age-matched controls). The conclusion was that this patient had "a degree of neurological involvement entirely compatible with definite signs of chronic mercury intoxication".

On January 26, 1977 he died in a hospital near his home in northwestern Quebec. There were delays in obtaining permission for autopsy and the body was embalmed and frozen. Permission was ultimately obtained and the autopsy was performed on 8 March 1977.

\section{Autopsy Report}

Autopsy showed no external abnormalities. The brain was found to be fixed by the embalming fluid and was removed intact for subsequent histopathological examination. The lungs were found to be enlarged, moderately firm and nodular, with a moderate quantity of mucopurulent secretion in the bronchi. Moderate myo- cardial hypertrophy was noted as were fatty changes in the liver. There was a slight renal enlargement. All other macroscopic findings were normal for an individual of this age. In addition to the brain, samples of heart, muscle, liver, kidney, thyroid, adrenals, gall bladder, testes, bone, and bone marrow were taken for measurement of mercury level and histology.

Histological examination showed the presence of severe broncho-pneumonia probably due to aspiration. A fatty liver was again noted.

It was concluded that death must be attributed to aspiration pneumonia.

A detailed histological examination of the brain was carried out on representative sections from all major regions of the cerebrum, basal ganglia, thalamus, brain stem, and cerebellum. Hematoxylin-eosin and myelin-Nissl stains were used. In all of the sections it was noted that the tissue was pale and in many areas there were eschemic neurons. There was no evidence of altered myelin or nerve cell loss with the exception of slight focal reduction in the numbers of Purkinje cells in the cerebellum. The latter was not considered to be significant in view of the patient's age. There was a slight increase in the number of Bergmann astrocytes at sites of Purkinje cell loss; otherwise, no reactive changes were encountered. There was moderate terminal narrowing of the basilar artery due to atherosclerosis.

Although no clear-cut evidence of changes attributable to mercury intoxication could be found, it should be pointed out that artefacts due to faulty preservation were numerous in this material. Distortion of the configuration of cells and separation of structures were particularly conspicuous. Histological evaluation was further complicated by the extensive pallor of staining and ischemic nerve cell changes representing hypoxic/ischemic damage related to the patient's terminal illness. Thus, while it can be stated that major nerve cell loss such as that described by Hunter and Russell (1954) was not present in this case, more subtle changes that might be detected with the use of special procedures or even with routine methods in better fixed material are not excluded.

\section{Tissue Mercury Levels}

The results of estimations of tissue total mercury levels are shown in Table I. The levels of mercury in the various embalming fluids which had been used, are also indicated.

In the brain and other organs, mercury

TABLE I

A comparison of mercury concentration found in tissues in this case versus tissue concentration reported in individuals poisoned with methylmercury.

\begin{tabular}{|c|c|c|c|c|c|c|c|c|c|}
\hline \multirow{3}{*}{$\begin{array}{l}\text { Clinical } \\
\text { Categories }\end{array}$} & \multirow{3}{*}{$\begin{array}{l}\text { Time from end } \\
\text { of exposure } \\
\text { to death } \\
\text { (Months) }\end{array}$} & \multirow{3}{*}{$\begin{array}{l}\begin{array}{c}\text { Age at } \\
\text { death }\end{array} \\
\text { (Years) }\end{array}$} & \multicolumn{7}{|c|}{ Concentration of total mercury $(\mu \mathrm{g} \mathrm{Hg} / \mathrm{g}$ wet wt) } \\
\hline & & & \multicolumn{3}{|c|}{ BRAIN } & \multirow{2}{*}{ Liver" } & \multirow{2}{*}{ Kidney } & \multirow{2}{*}{.Heart } & \multirow{2}{*}{ Spleen } \\
\hline & & & Whole & Cerebrum & Cerebellum & & & & \\
\hline This case ${ }^{\mathrm{b}}$ & 18 & 79 & & .32 & 0.40 & 2.5 & 5.1 & 0.43 & 0.15 \\
\hline $\begin{array}{l}\text { Minamata cases } \\
\text { of poisoning } \\
\text { (number) }\end{array}$ & $0.5-3$ & $34-62$ & $\begin{array}{c}2.6-25 \\
(11)\end{array}$ & & & $\begin{array}{c}22-70 \\
(10)\end{array}$ & $\begin{array}{c}21-144 \\
(10)\end{array}$ & & \\
\hline $\begin{array}{l}\text { Minamata case } \\
\text { of poisoning }\end{array}$ & 16 & 57 & 2.8 & & & 21.3 & 36.5 & & \\
\hline $\begin{array}{l}\text { Minamata case } \\
\text { of poisoning }\end{array}$ & 24 & 60 & 1.0 & & & 8.3 & 19.6 & & \\
\hline $\begin{array}{l}\text { Controls } \\
\text { Minamata area } \\
\text { 3I autopsies }\end{array}$ & & & $<0.1$ & & & $\leq 2$ & $\leq 3$ & & \\
\hline $\begin{array}{l}\text { Controls } \\
\text { Japan } \\
\text { (number) }\end{array}$ & & & & $\begin{array}{c}0.04-0.17 \\
(10)\end{array}$ & $\begin{array}{l}0.05-0.23 \\
(10)\end{array}$ & $\begin{array}{l}0.16-1.3 \\
(15)\end{array}$ & $\begin{array}{l}0.18-2.6 \\
(15)\end{array}$ & $\begin{array}{c}.023-0.13 \\
(15)\end{array}$ & $\begin{array}{c}0.021-0.14 \\
(13)\end{array}$ \\
\hline
\end{tabular}

"Liver values reported from autopsy cases in the 1971-72 Iraq outbreak were in the range 1.4-75.5 $\mu \mathrm{g} / \mathrm{g}$ (Magos et al 1976)

'Embalming Fluids

(i) Arterial compound $3.6 \mathrm{ng} / \mathrm{ml}$

(Total mercury)

$\begin{array}{ll}\text { (ii) Cell conditioner } & 1.2 \mathrm{ng} / \mathrm{ml} \\ \text { (iii) Cavity conditioner } 1.0 \mathrm{ng} / \mathrm{ml} \\ \text { (iv) Anticoagulamt } & 1.9 \mathrm{ng} / \mathrm{ml}\end{array}$

"Taken from Table 2.1 in "Minamata Disease" eds. T. Tsubaki and K. Irukayama. Elsevier Scientific Publishing Co., N.Y. (1971) p. 132.

"Taken from Table $I I I$ in Kitamura. S. et al. Mercury content in human tissue from Japan in Effects and dose-response relationships of toxic metals, ed GF Nordberg, Amsterdam. Elsevier, 1976 p. 294-295. 
levels are lower than the range identified by Japanese workers in diagnosed cases of poisoning but higher than levels found in a Japanese control group (Takeuchi \& Eto, 1977). Table I shows comparative figures for these groups. The Ja panese group died within a short period of time after exposure (probably less than three months) whereas in the present case death occured approximately 18 months after exposure. Table I, therefore, also gives tissue levels in two Japanese cases which most closely matched the case described here in terms of age, sex, brain weight, immediate cause of death (aspiration pneumonia), and the period of time between exposure and death (1 1/2 to 2 years). The tissue levels in these cases also exceeded the levels in the present case. Recently, work from Iraq on autopsies of individuals who had suffered from acute exposure to methylmercury (Al-Saleem et al., 1976; Magos et al., 1976), showed brain and liver mercury levels in a slightly higher range (brain 18-34 $\mu \mathrm{g} / \mathrm{g}$ ) than the Japanese findings.

\section{DISCUSSION}

The levels of mercury in brain (Table I) were above the normal range but below the minimum brain mercury level in adults associated with signs and symptoms which Nordberg (1976) states as being $1.2-3.4 \mu \mathrm{g} / \mathrm{g}$ for the most sensitive individuals. Since blood and hair mercury levels had fallen to a relatively low figure in the year preceding death, considerable tissue excretion of mercury may have occurred and brain mercury levels may well have been considerably higher at the time of clinical examination. Furthermore, recovery of cells may have occurred. Al-Damluji et al., (1976) noted that in mild to moderately affected cases a significant degree of functional improvement could be expected following cessation of exposure to methylmercury. The possibility of a reversible effect must, therefore, be considered.

The postmortem blood:brain mercury concentration ratio in this case was approximately $1: 10$. If it is assumed that this ratio was the same 18 months earlier, then the anticipated brain level would have been $3.5 \mu \mathrm{g} / \mathrm{g}$. This is in the range of concentrations in the two best matching cases in Japan (Table I). It is also well into Nordberg's "symptomatic" range mentioned earlier. Even if it is assumed that the $1: 10$ ratio is not applicable, the use of Nordberg's suggested 1:6 ratio yields a figure of $2.1 \mu \mathrm{g} / \mathrm{g}$ which is just below the Japanese case range but still well into the "symptomatic" range. Therefore, the hypothesis that this man had early signs and symptoms due to methylmercury at the time of clinical examinations in 1975, while not proven, is certainly plausible.

Possibly neurohistology is too blunt a tool at the levels of methylmercury being seen in Canada and the answers may lie in the fields of neurophysiology and biochemistry. It is recognized that methylmercury can damage important biochemical pathways, such as the pyruvate dehydrogenase system, which may not necessarily be evident pathologically. Syversen (1977) has reported that protein synthesis was inhibited in vivo in cerebellar neurons of rats at tissue concent rations between 1 and $1.5 \mu \mathrm{g} \mathrm{Hg} / \mathrm{g}$ wet weight, which concentration is in the range that should have occurred in 1975 in this patient. Since, in general, the effects of methylmercury appear to occur at about the same brain concentration in a variety of different species (Swedish Expert Group, 1971) the finding of biochemical injury in rats lends support to the hypothesis that this patient also experienced biochemical damage.

Barbeau et al. (1976) and Pritchard (1976) have noted the difficulties inherent in making a definitive clinical diagnosis in members of Indian groups exposed to environmental mercury in Canada. The opinion has been expressed that more detailed documentation of individuals, together with autopsy and neurohistopathology findings, would clarify the situation (Shepard, 1976). However, despite adequate knowledge of blood and hair levels over a three year period, plus clinical examinations, autopsy, extensive analysis of brain and tissue mercury levels, and neurohistology, a definitive diagnosis remains elusive in the present case. Despite the theoretical brain:blood ratio extrapolation discussed earlier, which the authors believe to be both significant and to fit the clinical findings, a definite diagnosis of mercury poisoning may still be challenged since, although the possibility of more subtle or transient effects is a valid premise, no mercury related pathology could be conclusively demonstrated.

It may therefore be concluded that:

1) The difficulties involved in resolving the question of diagnosis indicate the problem of detection of early or less severe effects in a population group. such as Canadian Indian people, exposed to methylmercury in the diet and stress the clear need for the development of sensitive and specific tests for the effects of methylmercury in man.

2) Evidence points to biochemical disturbances, which do not necessarily entail detectable histological damage, as the most likely basis for neurological effects which may be observed at the blood mercury levels being detected in Canadian Indians at the present time.

3) The patient whose case is presented did not exhibit the severe neurological damage associated with "Minamata disease". Repeated neurological tests and neurohistology failed to resolve conclusively the question of diagnosis of less severe neurological damage due to methylmercury.

4) The concept of silent damage postulated on animal experiments is not supported in this case.

5) Early senility postulated on a theoretical model of slightly accelerated loss of neurons did not occur in this 79 year old man.

6) Other approaches to clarifying the effects of methylmercury on the health of Canadian Indians, such as the current McGill University Epidemiology study (Health and Welfare Canada, 1978), are essential.

7) Given the present problems in early detection, regulatory agencies should continue to allow a substantial safety factor in setting standards to protect the general population. 


\section{ACKNOWI.EDGEMENTS}

We wish to thank Dr. Eisen and the Medical Staff of the Montreal Neurological Hospital. Dr. Wesner Thesce. Hopital St. Sauveur. Vald'Or and Dr. Chaude Saucier. Centre Hospitalier Isle-Dieu. Matagami. for the provision of clinical reports. We also thank Dr. Monique Saloce and the slaff of the Medical Services Branch Quebec Region. M. Jean-Pierre Farant and M Andre Chartrand of the Medical Services Branch laboratory, Ottawa, and Mr. Michae! R. Greenwood and the staff of the Mercury Laboratory. University of Rochester, N.Y. for ins alluable assistance. W' wish to acknowledge partial support from PHS Grant ES-01247.

\section{REFERENCES}

AL-DAMLUJI, S.F. and The Clinical Committee on Mercury Poisoning (1976) Intoxication due to alkylmercury-treated seed 1971-72 outbreak in Iraq: Clinical Aspects. In: Conference on intoxication due to alkylmercury-treated seed. Baghdad. Iraq. 9-13 Sept. 1974. Supplement to Vol. 53 of the Bulletin of the World Health Organization. W.H.O. Geneva pp. 65-81.

AL-SALEEM, T. and The Clinical Committee on Mercury Poisoning (1976) Levels of mercury and Pathological changes in patients with organomercury poisoning. In: Supplement to Vol. 53 of Bull. W.H.O. Geneva pp. 99-104.

AL-SHAHRISTANl, H., SHIHAB, K. and AL-HADDAD. I.K. (1976) Mercury in hair as an indicator of total body burden. In: Supp. to Vol. 53 of Bull. W.H.O., Geneva pp. $105-112$.

AMIN-ZAKI, L. ELHASSANI, S., MAJEED. M.A., CLARKSON. T.W.. DOHERTY. R.A., GREENWOOD, M.R. and GIOVANOLI-JAKUBCZAK, T. (1976) Perinatal methylmercury poisoning in lraq. Amer. J. Dis. Children 130. 1070-1076.

ARMSTRONG, F.A.J. and HAMILTON, A.L. (1973) Pathways of Mercury in a Polluted Northwestern Ontario Lake. In: Toxic Metals and Metal-Organic Interactions in Natural Waters. Ann Arbor Science Publishers, Michigan. pp. 131-156.

BAKIR, F., DAMLUJI, S.F., AMIN-ZAKI, L.. MURTHADA, M., KHALIDI. A., ALRAWI, N.Y., TIKRITI, S., DHAHIR, H.I. CLARKSON, T.W., SMITH, J.C. and DOHERTY, R.A. (1973) Methylmercury poisoning in Iraq. Science 181, 230-241.

BARBEAU, A., NANTEL. A. and DORLOT, F. (1976) Étude sur les effets médicaux et toxicologiques du mercure organique dans le Nord-Quest Québécois. Ministère des Affaires sociales du Québec, Québec.

BERKES, F. et al. (1972) Environmental Aspects of the Pulp and Paper Industry in Quebec. McGill University. Montreal. pp. $171-178$.

BISHOP. J.M. and NEARY, B.P. (1976) Mercury Levels in Fish from Northwestern Ontario, 1970-1975. Ministry of the Environment. Ontario.

CLARKSON. T.W. (1976) Exposure to methylmercury in Grassy Narrows and Whitedog Reserves. Report for Medical Services Branch, Health and Welfare. Canada.
Environment Canada and Environmental Protection Service, Quebec (1972) An Investigation into the Source and Distribution of Mercury in the Environment of Northwestern Quebec.

Health and Welfare Canada (1978) Joint Epidemiology Study on the effects of mercury. News Release $\$ 1978$ - 31. Montreal.

GANTHER. H.E.. GOUDIE. C.. SUNDE. M.L.. KOPECKY. M.J.. WAGNER. P.. OH. S.H. and HOEKSTRA. W.G. (1972) Selenium: Relation to decreased toxicity of methylmercury added to diets containing tuna. Science 175, 1122-1124.

GIOVANOLI-JAKUBCZAK, T., GREENWOOD, M.R., SMITH, J.C. and CLARKSON. T.W. (1974) Determination of Total and Inorganic Mercury in Hair by Flameless Atomic Absorption and of Methylmercury by gas chromatography. Clin. Chem. 20(2). 222-229.

GRANT. C.A. (1973) Pathology of experimental methylmercury intoxication: some problems of exposure and response. In: Mercury. Mercurials, and Mercaptans, (Miller, M.W. and Clarkson. T.W. eds) Charles C. Thomas, Springfield. Ill. pp. 294-310.

HARADA. M.. TADASHI. F.. TAKETOSHI. A.. SUSUMO, N.. (1976) Epidemiological and Clinical Study and Historical Background of mercury pollution on Indian Reservations in Northwest Ontario, Canada. Bulletin of Institute of Constitutional Medicine 26, 3.4, 169-184.

HUNTER, D. and RUSSELL. D.S. (1954) Focal Cerebral and Cerebellar atrophy in a human subject due to organic mercury compounds. J. Neurol. Neurosurg. Psychiat. 17. 235-24l.

JENSEN, S. and JERNELOV. A. (1969) Biological Methylation of Mercury in Aquatic organisms. Nature 223, 753-754.

KAHN. E. (1971) Perspective on tuna fish. New England J. Med. 285. 49-50.

KATSUMA. M. ed. (1968) Minamata Disease. Study Group of Minamata Disease, Kumamota University, Japan.

KERSHAW, T.. CLARKSON, T.W. and DHAHIR, P.H. (1979) The relationship between blood levels and dose of methylmercury in man. Submitted for publication.

KOLBYE. A. (1973) In: Proceedings of Conference on Heavy Metals in the Aquatic Environment (Krenkel, D.A. ed) Pergammon Press, Oxford

MAGOS, L. and CLARKSON, T.W. (1972) Atomic Absorption Determination of Total, Inorganic and Organic Mercury in Blood. J. Am. Off. Anal. Chem. 55, 966-971.

MAGOS, L., BAKIR, F., CLARKSON, T.W., AL-JAWAD, A.M. and AL-SOFFI, M.H. (1976) Tissue levels of mercury in autopsy specimens of liver and kidney. In: Supp. to Vol. 53 of Bull. W.H.O. Geneva pp. 93-97.

MORRISON, A.B. (1971) The Canadian approach to acceptable daily intakes of mercury in foods. In: Proceedings of Royal Society of Canada Symposium on Mercury in Man's Environment. 157-164.
NORDBERG. G.F. (1976) In: Effects and Dose Response Relationships of Toxic Metals. Elsevier Scientific Pub. Co.. Amsterdam pp. 80-85.

PHELPS. R.W., CLARKSON, T.W.. KERSHAW. T.G. and WHEATLEY. B. (1979) Interrelationships of Blood and Hair mercury concentrations in a North American population exposed to methylmercury. Submitted for publication.

PRICHARD, J.S. (1976) Letter to Dr, B. Wheatley. Medical Services Branch. Health and Welfare Canada.

SHEPARD, D.A.E. (1976) Methylmercury Poisoning in Canada. Canadian Medical Association Journal. Vol. 114: No. 5 . 46.3-472.

SKERFVING. S. and VOSTAL. D. (1972) Symptoms and Signs of intoxication. In: Mercury in the Environment. (Friberg, L. and Vostal. D. eds) CRC press. Cleveland, Ohio. pp. 93-107

SKERFVING. S. (1978) Interaction between Selenium and Methylmercury. Environmental Health Perspectives 25, 57-65.

Swedish Expert Group (1971) Methylmercury in Fish. A toxicologic-epidemiologic evaluation of risks. Report from an Expert Group. Nordisk Hygiensk Tidskrift. Suppl. 4 National Institute of Public Health. Stockholm.

SYVERSEN, T.L.M. (1977) Effects of methylmercury on in vivo protein synthesis in isolated cerebral and cerebellar neurons. Neuropath. and Appl. Neurobiol. 3, 225-236.

TAKEUCHI. T. and ETO. K. (1977) Pathology and Pathogenesis of Minamata Disease. In: Minamata Disease (Tsubaki, T, and Irukayama, K. eds.) Elsevier Scientific Pub. Co., Amsterdam pp. 103-141.

TSUBAK1, T., SATO, T.. KONDO, K., SHIRAKAWA, K.. KAMBAYASHI, K., HIROTA, K.. YAMADA, K., MURONE, 1. (1967) Oubreak of intoxication by organic mercury compounds in Niigata Prefecture: An epidemiological and clinical study. Japanese Journal of Medicine, 6. 32.

WEISS, B. and SIMON, W. (1975) Quantitative Perspectives on Long-term toxicity of methylmercury and similar poisons. In: Behavioral Toxicology, (Weiss. B. and Laties, V.G. eds) Plenum Publish. Co. New York. Chapter 16, pp. 429-434.

WHEATLEY, B. (1979) Mercury Program Review, Medical Services Branch. Health and Welfare Canada, Ottawa.

World Health Organization (1972) Evaluation of mercury, lead, cadmium and the food additives amaranth, diethylpyrocarbonate, and octyl gallate. W.H.O. Food Additives, Series \#4, W.H.O., Geneva.

World Health Organization (1974) The use of mercury and alternative compounds as seed dressings, (Joint FAO/WHO Meeting). W.H.O. Technical Report Series \#555 W.H.O., Geneva.

World Health Organization (1976) Environmental Health Criteria I. Mercury. W.H.O., Geneva. 